\title{
Head size and cognitive ability in nondemented older adults are related.
}

Citation for published version (APA):

Tisserand, D. J., Bosma, J. H. A., van Boxtel, M. P. J., \& Jolles, J. (2001). Head size and cognitive ability in nondemented older adults are related. Neurology, 56(7), 969-971.

https://doi.org/10.1212/WNL.56.7.969

Document status and date:

Published: 01/01/2001

DOI:

10.1212/WNL.56.7.969

\section{Please check the document version of this publication:}

- A submitted manuscript is the version of the article upon submission and before peer-review. There can be important differences between the submitted version and the official published version of record.

People interested in the research are advised to contact the author for the final version of the publication, or visit the DOI to the publisher's website.

- The final author version and the galley proof are versions of the publication after peer review.

- The final published version features the final layout of the paper including the volume, issue and page numbers.

Link to publication

\footnotetext{
General rights rights.

- You may freely distribute the URL identifying the publication in the public portal. please follow below link for the End User Agreement:

www.umlib.nl/taverne-license

Take down policy

If you believe that this document breaches copyright please contact us at:

repository@maastrichtuniversity.nl

providing details and we will investigate your claim.
}

Copyright and moral rights for the publications made accessible in the public portal are retained by the authors and/or other copyright owners and it is a condition of accessing publications that users recognise and abide by the legal requirements associated with these

- Users may download and print one copy of any publication from the public portal for the purpose of private study or research.

- You may not further distribute the material or use it for any profit-making activity or commercial gain

If the publication is distributed under the terms of Article $25 \mathrm{fa}$ of the Dutch Copyright Act, indicated by the "Taverne" license above, 
precursor protein and modulation by apolipoprotein E. Nature 1997; 388:878-881.

7. Karussis DM, Michaelson DM, Abramsky O, Mizrachi-Koll R, Korczyn $\mathrm{AD}$, Chapman J. Induction of experimental allergic encephalomyelitis (EAE) in apolipoprotein E (APOE) deficient mice. Neurology 1999; 52(suppl 2):A339. Abstract.

8. Drory VE, Birnbaum M, Korczyn AD, Chapman J. Association of APOE $\varepsilon 4$ allele with survival in amyotrophic lateral sclerosis. J Neurol Sci 2001;190:17-20.

9. Schiefermeier M, Kollegger H, Madl C, et al. The impact of apolipoprotein $\mathrm{E}$ genotypes on age at onset of symptoms and phenotypic expression in Wilson's disease. Brain 2000;123:585-590.

10. Chapman J, Korczyn AD, Karussis DM, Michaelson DM. The effects of APOE genotype on age of onset and progression of neurodegenerative diseases. Neurology 2001;57:1482-1485.

\section{Cerebral white matter lesions and subjective cognitive dysfunction: The Rotterdam Scan Study}

To the Editor: Recent findings from the Rotterdam Scan Study ${ }^{1}$ further support the importance of cognitive complaints by demonstrating clear associations with white matter lesions in the absence of objective cognitive dysfunction. $A P O E$ genotype represents another proxy measure of risk for dementia, but associations with subjective cognitive dysfunction have received little research attention. In 1999, Small et al. ${ }^{2}$ reported an association between worse self-appraised memory and presence of the APOE$\varepsilon 4$ allele in a sample of volunteers with memory complaints. My colleagues and I were recently able to confirm this finding in a community-based African-Caribbean sample aged 55 to $75 .^{3}$ Subjective memory impairment was derived from a validated screening instrument ${ }^{4}$ and categorized as a binary variable. Objective cognitive function appeared to modify rather than explain this association. Odds ratios for the association between $A P O E-\varepsilon 4$ and subjective memory impairment, adjusted for depression and somatic complaints, were 1.15 (95\% CI 0.25 to 5.20) for those with Mini-Mental State Examination (MMSE) scores of 26 to $30,3.45$ (1.08 to 11.1) for those with scores of 21 to 25 , and 6.13 (0.97 to 38.8 ) for those with scores below 21 . If $A P O E-\varepsilon 4$ is taken to represent risk for dementia, then self-appraised risk appeared to become more accurate in the presence of mild cognitive impairment. This pattern of association contrasts with those reported by de Groot et al., ${ }^{1}$ who found strong associations between periventricular white matter lesions and reported progression of cognitive dysfunction in those with the best objective performance. However, it is entirely conceivable that complaints associated with $A P O E$ genotype may differ in nature from those associated with white matter disease. $A P O E$ genotype has presumably been ascertained on Rotterdam Scan Study participants and analyses of associations with subjective dysfunction in this cohort hopefully will provide further clarification.

If subjective cognitive dysfunction represents an early marker of risk for cognitive decline and, ultimately, dementia, obvious questions arise concerning preventative interventions. However, people who show subjective dysfunction on screening instruments are likely to be a very different group than those who take their cognitive complaints to health care professionals. Factors determining self-presentation are poorly understood. Until these factors are adequately investigated, or unless population-level screening is introduced for subjective complaints, early preventative interventions are likely to be restricted unfairly to the minority at risk who find their way to secondary or tertiary care services.

\section{Robert Stewart, MSc, MRCPsych, London, United Kingdom}

Reply from the Authors: We appreciate Dr. Stewart's interest in our report ${ }^{1}$ and his work on the relation between $A P O E$ genotype, subjective memory impairment, and objective cognitive function. Dr. Stewart suggests that our findings that cerebral white matter lesions are particularly associated with subjective cognitive dysfunction in the absence of measurable cognitive dysfunction contradict his finding that the $A P O E-\varepsilon 4$ genotype is associated with worse self-appraised memory, particularly in the presence of objective cognitive dysfunction. ${ }^{3}$

We believe these findings are not necessarily contradictory. To date, the association between $A P O E-\varepsilon 4$ and white matter lesions has not been established, with studies failing to find such an association ${ }^{5-7}$ outnumbering studies reporting an association. ${ }^{8}$ It is therefore conceivable that the pathophysiologic mechanism that leads to cognitive decline is different for white matter lesions than it is for $A P O E-\varepsilon 4$. This fits the observation that the effects of white matter lesions and the $A P O E$ - $\varepsilon 4$ allele on cognitive decline are at least additive. ${ }^{9}$ The association between $A P O E-\varepsilon 4$ and subjective cognitive dysfunction has been the subject of only a limited number of studies with a relatively small number of participants, as pointed out by Dr. Stewart. In preliminary analyses from the Rotterdam Scan Study (477 available APOE determinations), ${ }^{1}$ we could not confirm an association between $A P O E$ status and subjective cognitive dysfunction, nor could we replicate the modification by objective cognitive function. Although the findings by Stewart et al. $^{3}$ are interesting, we believe further research on this subject is needed to clarify the association between $A P O E$ status, white matter lesions, subjective cognitive function, and objective cognitive dysfunction.

Jan Cees de Groot, MD PhD, Groningen; Monique M.B. Breteler, MD, PhD, Rotterdam, the Netherlands

Copyright (C) 2001 by AAN Enterprises, Inc.

\section{References}

1. de Groot JC, de Leeuw F-E, Oudkerk M, Hofman A, Jolles J, Breteler MMB. Cerebral white matter lesions and subjective cognitive dysfunction. The Rotterdam Scan Study. Neurology 2001;56:1539-1545.

2. Small GW, Chen ST, Komo S, et al. Memory self-appraisal in middleaged and older adults with the apolipoprotein E-4 allele. Am J Psychiatry 1999;156:1035-1038.

3. Stewart R, Russ C, Richards M, Brayne C, Lovestone S, Mann A. Depression, APOE genotype and subjective memory impairment: a crosssectional study in an African Caribbean population. Psychol Med 2001; 31:431-440.

4. Copeland JRM, Kelleher MJ, Kellet JM, Gourlay AJ. A semi-structured clinical interview for the assessment of diagnosis and mental state in the elderly: the Geriatric Mental State Schedule. Psychol Med 1976;6:439449 .

5. Bartres-Faz D, Junque C, Clemente IC, et al. MRI and genetic correlates of cognitive function in elders with memory impairment. Neurobiol Aging 2001;22:449-459.

6. Kuller LH, Shemanski L, Manolio T, et al. Relationship between ApoE, MRI findings, and cognitive function in the Cardiovascular Health Study. Stroke 1998;29:388-398.

7. Schmidt H, Schmidt R, Fazekas F, et al. Apolipoprotein E e4 allele in the normal elderly: neuropsychologic and brain MRI correlates. Clin Genet 1996;50:293-299.

8. Bronge L, Fernaeus SE, Blomberg M, et al. White matter lesions in Alzheimer patients are influenced by apolipoprotein $\mathrm{E}$ genotype. Dement Geriatr Cogn Disord 1999;10:89-96.

9. Carmelli D, DeCarli C, Swan GE, et al. The joint effect of apolipoprotein $\mathrm{E}$ epsilon4 and MRI findings on lower-extremity function and decline in cognitive function. J Gerontol A Biol Sci Med Sci 2000;55:M103-M109.

\section{Head size and cognitive ability in nondemented older adults are related}

To the Editor: We read with interest and a certain aura of déjà vu the report by Tisserand et al. ${ }^{1}$ on the relationship between head size and cognitive ability. Beyond issues such as differential average size of the brains of men and women or the science of phrenology and other theories on the association between head structure and personality, ${ }^{2,3}$ this work brings to mind the story of Paul Broca's claim that brain size is associated with intelligence. ${ }^{4}$ His theory was based in part on the postmortem of George Curvier, the founder of paleontology, who was found to possess a very large brain (weighing 1830 grams). Because no measures of the skull were taken, the hat of the scientist was located and presented as circumstantial evidence for his enormous head (and brain) size. Nevertheless, the assertion that the head size of Curvier was due to arrested hydrocephalus could not be disproved, so the evidence was dismissed.

Ever since 1861, when Broca was occupied with this scientific strife, until lately, when new information on Albert Einstein's brain hit the tabloids and the scientific community, ${ }^{5}$ the size of brains has been a juicy item (Turgenev's brain weighed more than 2000 grams, whereas Anatole France's weighed in at only 1017 grams ${ }^{4}$ ). However, before concluding that size does matter and that Paul Broca might have been, at the end of the day, correct, this report does not detail how head size was corrected for body weight, individual height, nutrition, and sex, as well as race. 
Therefore, we think that any conclusion from this report should be regarded with some caution.

Israel Steiner, MD, J.P. Newman, PhD, Jerusalem, Israel

Reply from the Authors: We acknowledge that relating anthropometric measures to mental abilities is a charged research topic. Too often, human history has shown that associating intellectual abilities or personality characteristics with individual differences in physical appearance can lead to discrimination of certain groups of people. However, the purpose of our study was to investigate the relationship between head size and cognitive performance in elderly subjects while explicitly adjusting for individual differences (e.g., age, sex, education). Race was no issue in our study, ${ }^{1}$ as all participants were Caucasian. Furthermore, neither height nor socioeconomic background (assumed to reflect nutritional and other developmental factors early in life) significantly influenced the head size-cognition associations that we found.

While leaving aside the discussion of whether it is plausible to suggest the existence of a relationship between a global measure such as head size and specific mental abilities, the consistency of the findings is remarkable. In studies with demented patients, a relationship between head or brain size and disease severity has been reported repeatedly. ${ }^{6-8}$ This head size-cognition association, albeit small, also seems to apply to healthy elderly individuals. ${ }^{1,9}$ As described in our article, ${ }^{1}$ these studies have been taken as evidence for a brain reserve hypothesis; that is, larger brains may provide a buffer against cognitive deterioration.

Danielle Tisserand, MSc, Hans Bosma, PhD, Martin P.J. Van Boxtel, MD, PhD, Jelle Jolles, PhD, Maastricht, the Netherlands

Copyright $\odot 2001$ by AAN Enterprises, Inc.

\section{References}

1. Tisserand DJ, Bosma H, Van Boxtel MP, Jolles J. Head size and cognitive ability in nondemented older adults are related. Neurology 2001;56: 969-971.

2. Hoff TL. Gall's psychophysiological concept of function: the rise and decline of "internal essence." Brain Cogn 1992;20:378-398.

3. Liberini P, Spano P. From the mind to the brain: an unusual pathway. J Hist Neurosci 2000;9:41-45.

4. Gould SJ. The Panda's thumb. More reflections in natural history. London: Penguin Books, 1980.

5. Witelson SF, Kigar DL, Harvey T. The exceptional brain of Albert Einstein. Lancet 1999;353:2149-2153.

6. Graves AB, Mortimer JA, Larson EB, Wenzlow A, Bowen JD, McCormick WC. Head circumference as a measure of cognitive reserve. Association with severity of impairment in Alzheimer's disease. $\mathrm{Br} \mathrm{J}$ Psychiatry 1996;169:86-92.

7. Mori E, Hirono N, Yamashita H, et al. Premorbid brain size as a determinant of reserve capacity against intellectual decline in Alzheimer's disease. Am J Psychiatry 1997;154:18-24.

8. Schofield PW, Logroscino G, Andrews HF, Albert S, Stern Y. An association between head circumference and Alzheimer's disease in a population-based study of aging and dementia. Neurology 1997;49:3037.

9. Reynolds MD, Johnston JM, Dodge HH, DeKosky ST, Ganguli M. Small head size is related to low Mini-Mental State Examination scores in a community sample of nondemented older adults. Neurology 1999;53: $228-229$.

\section{Cerebral sinus thrombosis with tamoxifen}

To the Editor: The case reported by Finelli and Schauer ${ }^{1}$ raises interesting points about the physiologic patterns of venous flow across the transverse sinuses. In 50 to $80 \%$ of cases, there is an asymmetry in flow across the transverse sinuses, with up to $5 \%$ of cases displaying agenesis of part or all of one transverse sinus, which should not be confused with sinus thrombosis. ${ }^{2,3}$ Therefore, an alternative explanation may exist for the large right temporal lesion presented in figure $1 \mathrm{~A}$ in the original article,$^{1}$ especially because the right cerebellar cortex looks normal on the axial images, and flows down the superior sagittal sinus, which takes a smooth path as it curves at the torcula into the left transverse sinus. No jagged or irregular filling defects are seen in the area of the presumed atretic right transverse sinus to suggest an acute sinus thrombosis. The bright signal in the right sigmoid sinus in figure $1 \mathrm{~B}$ in the original article ${ }^{1}$ is not diagnostic for an occlusion, and slow flow enhancement is a physiologic phenomenon that needs to be considered. The right temporal lobe is drained by the vein of Labbe; when this is occluded or congested by an acute transverse sinus occlusion, collateral paths can open in the right temporal lobe to drain blood anteriorly via the superficial middle cerebral vein or upward by the vein of Trolard into the superior sagittal sinus. However, when the traverse sinus is acutely occluded, edematous changes within the adjacent cerebellum would be expected. Because the cerebellum looks normal but the right temporal lesion appears so large, a complete and acute occlusion of the transverse sinus appears unlikely from the information presented.

Michael A. Meyer, MD, Buffalo, $N Y$

Reply from the Authors: Despite the absence of flow on MR venography, Dr. Meyer comments that increased signal in the sigmoid sinus on fluid-attenuated inversion recovery (FLAIR) MRI is not diagnostic for occlusion and suggests that this may represent the physiologic phenomena of slow flow. Diagnostic pitfalls in neuroimaging occur with dural sinus thrombosis and have been the topic of recent reviews on this subject. ${ }^{4-6}$ The most compelling noninvasive neuroimaging evidence for venous sinus thrombosis relies on the use of various MRI sequences and MRI changes over time.$^{6}$ As such, concern for accurate diagnosis is appropriate with signal abnormality on a single MRI sequence.

In our patient, in addition to increased signal in the sigmoid sinus on the FLAIR sequence, it was the corresponding increased signal on $\mathrm{T} 1$ and decrease on gradient echo, as well as equal vessel caliber and the evolutionary signal change on T1 and FLAIR according to hemoglobin degradation, features not seen with physiologic flow, that led to the diagnosis of venous sinus thrombosis.

Pasquale F. Finelli, MD, Peter K. Schauer, MD, Hartford, CT

Copyright $\odot 2001$ by AAN Enterprises, Inc.

\section{References}

1. Finelli PF, Schauer PK. Cerebral sinus thrombosis with tamoxifen. Neurology 2001;56:1113-1114.

2. Dora F, Zileli T. Common variations of the lateral and occipital sinuses at the confluem sinuum. Neuroradiology 1980;20:23-27.

3. Kaplan HA, Browder A, Browder J. Narrow and atretic transverse dural sinuses: clinical significance. Ann Otol Rhinol Laryngol 1973;82:351354 .

4. Ayanzen RH, Bird CR, Keller PJ, McCully FJ, Theobald MR, Heiserman JE. Cerebral MR venography: normal anatomy and potential diagnostic pitfalls. Am J Neuroradiol 2000;21:74-78.

5. Provenzale JM, Joseph GJ, Barboriak DP. Dural sinus thrombosis: findings on CT and MR imaging and diagnostic pitfalls. AJR Am J Roentgenol 1998;170:777-783.

6. Bianchi D, Maeder P, Bogousslavsky J, Schnyder P, Meuli RA. Diagnosis of cerebral venous thrombosis with routine magnetic resonance: an update. Eur Neurol 1998;40:179-190.

\section{Adverse long-term effects of brain radiotherapy in adult low-grade glioma patients}

To the Editor: We were struck by an article in Neurology ${ }^{1}$ suggesting adverse effects of radiation therapy in patients with "low grade glioma." This report, based on an initial experience in 160 patients, provides retrospective evidence that for survivors there is some risk of cognitive dysfunction in patients who for the most part received radiation therapy using techniques that have been abandoned for more than 10 years. The authors note themselves that this retrospective report "cannot exclude the possibility that patients with poor performance and more anaplastic tumors were selected for radiation therapy." We believe the striking issue, not discussed by the current report, was the overall very poor outcome for patients with low-grade glioma. It should be noted that the patients included were Grade 1 (pilocytic astrocytoma) and represented a mixed series of astrocytic, oligoastrocytic, or pure oligodendrogial tumors, some of which contained anaplastic foci (clearly not low-grade). Patients were treated with a variety of techniques. At the time of the review, the vast majority of the patients had died of progression of their disease, and the median survival was approximately 7 years. This is in line with other reports detailing the dismal prognosis of patients erroneously called "low-grade glioma patients." Most of these patients had whole-brain radiation therapy, a technique that was abandoned in clinical trials for malignant glioma over a decade ago. The type of radiation therapy (linear accelerator, cobalt, etc.) is not specified. 